\title{
Embracing Education and Contesting Americanization: A Reexamination of Native Hawaiian Student Engagement in Territorial Hawai'i's Public Schools, 1920-1940
}

\section{Derek Taira}

This article explores the efforts of Native Hawaiian students to appropriate and take control of their schooling as part of a broad Indigenous story of empowerment during Hawai i's territorial years (1900-1959). Histories of this era lack a visible Indigenous presence and contribute to the myth that Natives passively accepted the Americanization of the islands. This article challenges this myth by examining Native student writings to tell a story of Native involvement in education as a pragmatic strategy designed to advance distinctly Indigenous interests through the American education system. These stories reveal schools as complex sites of negotiation where Native students regularly navigated sociocultural pressure from their friends, parents, teachers, and America's growing presence in the islands while testing and exploring their own identities.

The white fathers from the land of the free decided my people should go to school. Hadn't they always been to school? Were not the great out of doors their books, wherein they learned the things they needed to know the most? Superimposition and education were brought about without regard for the elements in my peoples' culture that were worth saving. I am still a Hawaiian and I am proud of it. I am no different from you. ${ }^{1}$

In his essay "I Am a Hawaiian," Native author and educator Charles W. Kenn questioned the benevolence of white educators who claimed to meet his people's schooling needs. His essay, published in Paradise of the Pacific, a travel magazine about Hawai'i circulated across the US, rejected the familiar image of happy, passive Natives and, instead, offered an Indigenous voice critical of American education and its

Derek Taira is an Assistant Professor in the Department of Educational Foundations

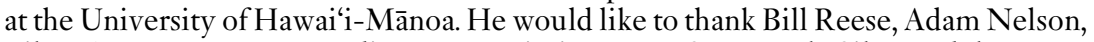
Eileen Tamura, Nancy Beadie, Bruce Kaimi Watson, Sean Keola Silva, and the anonymous HEQ reviewers for their thoughtful feedback.

${ }^{1}$ Charles W. Kenn, "I Am a Hawaiian," Paradise of the Pacific 48 (Nov. 1936), 21. 
assimilationist policies. As a product of the same public schools he criticized, Kenn used his command of the English language and knowledge of Native Hawaiian history to broadcast to the nation that he was "still a Hawaiian" and "proud of it."

Student archival sources support Kenn's defiant message. Life histories written by Native students bear testimony to their creativity, adaptability, and resiliency in the face of the Americanization campaign white continental educators avidly pursued in Hawai'i's public schools. They bring to light hidden stories about what the American educational system meant to many: a resource for survival. Far from passive victims of assimilation, Native students expressed in their writings how they selectively appropriated aspects of their schooling to negotiate the Americanization process while retaining their cultural identity. Collectively, their stories offer a critical counternarrative highlighting how many Native Hawaiians remained culturally proud during Hawai'i's territorial period and turned to schooling as a deliberate response to foreign forces marginalizing their culture and community.

Native student accounts do not reveal any larger movement of organized resistance capable of destabilizing either the American presence in Hawai $i$ or the educational system. Rather, they demonstrate that Native identity failed to disappear upon US annexation in 1898 and continued to persevere throughout the twentieth century. While not equal in visibility to later and more demonstrative forms of anticolonial protest, Native students' subtler expressions of defiance and refusal broaden the lens of resistance to include a greater range of examples of noncompliance and rejection of assimilation. This view requires understanding student agency as a measured oppositional response, often subtle, to schools' attempts to control students' minds, bodies, and actions. Native Hawaiian students resisted their victimization through strategies that allowed them to retain their dignity, some degree of freedom, and a positive sense of themselves in a system they felt they could not substantially change. ${ }^{2}$

This article uses a range of student-generated sources that were part of a survey on race relations in Hawaili conducted from 1924 to 1926. The survey results illuminate the ways in which Native Hawaiian students and their families viewed public schooling as a vehicle for success and empowerment in an Americanized Hawai $i$. Specifically, this article discusses student responses around four

\footnotetext{
${ }^{2}$ Myriam Vučković, Voices from Haskell: Indian Students between Two Worlds, 1884 1928 (Lawrence: University Press of Kansas, 2008), 127, 223; and Brenda J. Child, Boarding School Seasons: American Indian Families, 1900-1940 (Lincoln: University of Nebraska Press, 2000), 100.
} 
main themes: student motivation, family and teacher support, language acquisition and loss, and race. As I will argue, Native students attended school to master the English language, learn about the world and America, and obtain skills and credentials for social and economic advancement. They did so well aware of the inconsistencies in the rhetoric and reality of Americanization in the schools, the dangers assimilation posed to their Native identity, and the presence of white privilege and racism as hurdles to their success. Fortunately, students did not face these challenges alone. In most cases, their families represented a critical support network, nurturing students' Native identity while encouraging their pursuit of knowledge, training, and Englishlanguage proficiency. Actualizing this vision came at a high price: many families stopped speaking Hawaiian at home to ensure that their children obtained English proficiency. While this was a painful sacrifice, parents and students remained proud of their indigeneity and viewed schools - the most intimate of sites for Americanization - as the best means to prepare for their future as Native Hawaiians.

Despite being a critical source for understanding the complexity of the Native Hawaiian experience with American schooling, Native student writings remain absent within extant historiographies of territorial Hawai' $i$ and Hawaiian education. Previous histories of the territory typically celebrate the Americanization of the islands, promoting an American-centric progressive narrative touting the United States' "unique commitment" to the ideals of individual liberty, equality, and freedom as key factors in Hawai'i's political development. Such narratives depict the islands as possessing a "white soul," relegating Native participation and existence to a footnote in territorial history. ${ }^{3}$ This historical framing situates the progress of the islands within the manifest destiny of the United States and presumes the inevitability of Hawai'i's annexation as a fitting national achievement. In this telling, Native Hawaiians were unenthusiastic but realized they could no longer resist "progress" or bring back the past and, therefore, accepted their new political identity as "Hawaiian Americans"-a lost generation that assimilated by embracing American culture taught in Hawai'i's public schools. ${ }^{4}$

${ }^{3}$ Gunja Sengupta, "Elites, Subalterns, and American Identities: A Case Study of African-American Benevolence," American Historical Review 109, no. 4 (Oct. 2004), 1112-13.

${ }^{4}$ Roger J. Bell, Last Among Equals: Hawaiian Statehood and American Politics (Honolulu: University of Hawai'i Press, 1984), 37, 289-96; Davianna Pomaika'i McGregor, "Engaging Hawaiians in the Expansion of the U.S. Empire," Journal of Asian American Studies 7, no. 3 (Oct. 2004), 218; Davianna Pomaika'i McGregor, "Aina Ho'opulapula: Hawaiian Homesteading," Hawaiian Journal of History 24 
As "Native stories," student narratives represent "sources of survivance" that complicate this historical understanding of Native Hawaiian docility during the territorial period. ${ }^{5}$ They expose the presence of Natives who participated in the territorial educational system but contested Americanization by affirming their indigeneity. They contest historical narratives of submissiveness, victimization, and weakness by presenting "counter-narratives of worth" highlighting the ways in which Natives struggled, strategized, and fought to survive in an environment hostile to their identity. ${ }^{6}$ Yet, rather than reconnecting Natives to a more complex past that restores their ancestors to them as being as "complicated and as capable and as troubled as anyone else," most twentieth-century Hawaiian histories emphasizes how haole (whites) took so much away from Natives that they had nothing left to fight for-nothing left to "give one another." ${ }^{7}$ This article uses Native stories to challenge this assumption of passivity as a general Indigenous response to Americanization. It does not seek to minimize the damaging effects of Americanization but, instead of focusing on what was done to Native Hawaiians, it exposes "what they did with what was done to them." 8

Since the late 1980s, scholars of Indian boarding schools have shifted from a policy-oriented focus on these institutions to an understanding of how Native students navigated and negotiated the educational system. ${ }^{9}$ No such history exists for Native Hawaiians. Recent histories discussing Native Hawaiians' experiences with Americanization reflect earlier studies on Indian boarding schools emphasizing the aims of white schoolmen and policymakers. ${ }^{10}$ This top-down approach, though effective in discussing the attitudes of

(1990), 33; and Davianna McGregor-Alegado, "Hawaiians: Organizing in the 1970s," Amerasia Journal 7, no. 2 (Oct. 1980), 33.

${ }^{5}$ Gerald R. Vizenor, ed., Survivance: Narratives of Native Presence (Lincoln: University of Nebraska Press, 2008), 11; and Julie Kaomea, "Education for Elimination in Nineteenth-Century Hawai'i: Settler Colonialism and the Native Hawaiian Chiefs' Children's Boarding School," History of Education Quarterly 54, no. 2 (May 2014), 139.

${ }^{6}$ Charles M. Payne, "Countering the Master Narratives: The 'Why?' of Education for Liberation," Voices in Urban Education 34 (Summer 2012), 8-9.

${ }^{7}$ Payne, "Countering the Master Narratives," 8.

${ }^{8}$ As quoted by Payne, "Countering the Master Narratives," 10.

${ }^{9}$ Kevin Whalen, "Finding the Balance: Student Voices and Cultural Loss at Sherman Institute," American Behavioral Scientist 58, no. 1 (Jan. 2014), 130.

${ }^{10}$ Maenette K. P. Ah Nee Benham and Ronald H. Heck, Culture and Educational Policy in Hawaii: The Silencing of Native Voices (Mahwah, NJ: Lawrence Erlbaum Associates, 1998); and C. Kalani Beyer, "The Connection of Samuel Chapman Armstrong as Both Borrower and Architect of Education in Hawai'i," History of Education Quarterly 47, no. 1 (Feb. 2007), 23-48. 
white educators, fails to capture how Native students understood, experienced, and responded to school policies, curriculum, and racism.

Native student writings reveal these critical viewpoints. They disrupt the "passive" narrative of Native compliance by revealing the many ways in which Hawaiian youth engaged the school system to survive settler-colonial society and resist complete assimilation. Their reactions to Americanization ranged from complete rejection to open enthusiasm, as many students turned schooling into an opportunity for advancement. Like their Native American counterparts, Hawaiian students often did not adopt a sense of inferiority. Rather, students selectively incorporated those aspects of their schooling that ensured their individual and collective survival and well-being. In the end, the Americanization experience for Native Hawaiians in the territorial schools cannot be framed simply as an "either/or" phenomenon of passive assimilation or defiant resistance. Instead, student views reveal a complex and paradoxical story of Native youths shaping their own educational experiences in ways that were influenced, but not defined, by the project of assimilation.

Student stories also challenge how historians view "resistance" and underscore students' agency. Students were neither free agents shaping themselves as they pleased nor blank sheets awaiting the imprint of their schools. While the formation and implementation of assimilation policies reveal the intentions of white educators, they can only tell one side of the "Americanization" story. Student-generated sources are necessary to provide a more complete picture. Their perspectives sometimes challenge dominant narratives and sometimes complement them. In this way, they fill a critical gap in the history of Indigenous education by showing how students selectively received, engaged, and rejected various aspects of their schooling. This interpretative act of "turning the power" on the very institutions meant to transform Native students demonstrates the importance of student narratives in defining the various forms of student resistance. ${ }^{11}$ Doing so reveals a wider, more dynamic, and considerably more complex combination of opposition and resiliency by Native peoples as they empowered themselves to survive in a hostile environment.

${ }^{11}$ Clifford E. Trafzer, Jean A. Keller, and Lorene Sisquoc, "Origin and Development of the American Indian Boarding School System," in Boarding School Blues: Revisiting American Indian Educational Experiences, ed. Clifford E. Trafzer, Jean A. Keller, and Lorene Sisquoc (Lincoln: University of Nebraska Press, 2006), 1-3. 


\section{Student Histories and Surveys}

In 1926, William C. Smith, a visiting sociology professor at the University of Hawai $i$ from the University of Southern California, distributed a research questionnaire to students at ten public and private intermediate and senior high schools, the University of Hawaili, and the Territorial Normal and Training School. Composing over several dozen questions, Smith asked the following: when and where students were born; the size of their families; their parents' occupation, educational history, and ethnic background; student attitudes on the languages spoken and customs practiced at home; their life ambitions; their views on race; and how they conceptualized their political identity as Americans. However, while seemingly mundane and straightforward, this survey was anything but simple.

The inspiration for Smith's questionnaire came while he was a researcher for the Survey of Race Relations on the Pacific Coast. A two-year research project (1924-1926) led by University of Chicago sociologist Robert E. Park and funded through the Institute of Social and Religious Research, the survey investigated the assimilation process and lived experiences of "Orientals" in states along the US West Coast. ${ }^{12}$ Smith, like Park, considered Hawai' $i$ the "ultimate racial laboratory" - a "fantasy island" perfect for observing the racial "hybridization" occurring among the various ethnicities in the islands. ${ }^{13} \mathrm{He}$ was particularly fascinated with the second-generation Asian experience and their feelings of alienation and marginality in non-Asian social environments. As a result, he sought personal narratives capturing the overall feelings, impressions, and reactions of Asian students to language- and assimilation-related issues. His methodology provided him with samples from a wide age range between thirteen and twentyfour.

Smith sought to explain how American life contributed to the formation of a distinctly "Oriental American cultural consciousness."14 Pulling snippets from student survey responses, Smith pieced together extensive quotes to portray student feelings of being "caught between two worlds" as "holistic representations" of second-generation Asians. In this way, he transformed singular moments of marginality in numerous students' lives into a "defining characteristic of racialized

${ }^{12}$ The institute was a New York-based organization that provided Rockefeller Foundation funds for social science projects. Henry Yu, Thinking Orientals: Migration, Contact, and Exoticism in Modern America (New York: Oxford University Press, 2002), $20-23$.

\footnotetext{
${ }^{13} \mathrm{Yu}$, Thinking Orientals, 81-82.

${ }^{14} \mathrm{Yu}$, Thinking Orientals, 104.
} 
existence" for all Asians in America. ${ }^{15}$ This category of analysis, supported by his selective use of "Oriental American" student narratives, formed the basis of his publications during the 1920s and 1930s.

Smith was less interested in analyzing the Native Hawaiian experience with Americanization and marginality. Nevertheless, he amassed dozens of Native student survey responses, thus providing one of the few extant sources describing how Native Hawaiians experienced schooling during the territorial period. These student writings make up a significant component of the data for this article. Native students penned 10 percent, or 130, of the roughly twelve hundred questionnaires. This article focuses on 20 of the 130. No data source, of course, is perfect. While teachers encouraged students to write autobiographies as part of the survey, the students often chose not to compose their essays as personal memoirs. Since teachers solicited these papers for a famous white continental researcher, they possibly, either directly or indirectly, pressured students to project pro-American and/or pro-English-language positions. In addition, these papers do not take into account the number of students who forgot their assignment, were absent, or felt too embarrassed about their English-language skills to complete their autobiographies. ${ }^{16}$

While these twenty student accounts offer rare and critical insights into the educational history of Native Hawaiians during the territorial period, they cannot be viewed as representative. Of the tens of thousands of Indigenous students who entered the public schools, the twenty surveys chosen for this article only reveal the experiences of a select few during the late 1920s-those who achieved advanced English-language proficiency, received positive familial and community support for their schooling, and either pursued post-secondary education opportunities or expressed their ambition to do so.

Despite these limitations, the twenty survey responses reveal a collective emphasis on resiliency. Yet this was not the view in the majority of the 130 surveys, which displayed a range of experiences and attitudes. Student replies were often shaped, to varying degrees, by perceptions of what their teachers expected to hear as well as the survey questions' stress on race and cultural mixing. Over half of the 130 responses are either incomplete and/or brief, possibly due to author indifference to the assignment. Nearly a quarter of these 130 surveys are more substantial in length but offer minimal attitudinal

${ }^{15} \mathrm{Yu}$, Thinking Orientals, 101, 103.

${ }^{16}$ Sarah Julianne Roberts, "Nativization and the Genesis of Hawaiian Creole," in Language Change and Language Contact in Pidgins and Creole, ed. John H. McWhorter (Philadelphia: John Benjamins Publishing, 2000), 277-78. 
evidence of Indigenous pride. The remaining twenty responses articulate strong visions of Native resilience and survivance in the face of Americanizing efforts and form the core source of evidence for this article.

In these twenty surveys, students produced thoughtful and informative narratives revealing how they navigated and resisted Americanization in ways that challenge the myth of Native passivity during the territorial period. One clear example is how several Native students openly asserted pride in their indigeneity, often self-identifying as "part Hawaiian." Such expressions were unprompted by any specific question and thus not a focus of Smith's survey. This understanding helps reinforce the serendipitous significance of those who plainly professed their indigeneity as evidence of an assertive Indigenous consciousness that contested Americanization.

This was not the case with all Native students. In surveys not included in this article, students either did not emphasize or embrace their Native heritage. Instead, they tended to list Hawaiian as simply one of their other ethnicities, with some even identifying more with their non-Native backgrounds. That Native students racially selfidentified in different ways is not surprising. It's tough to imagine how any Native Hawaiian child's identity could have completely withstood the impacts and pressures of America's fascination with race and assimilation, as well as the diverse cultural values at home and school. Also, they were constantly forced to negotiate their adherence to Native practices, language, and cultural beliefs in a settlercolonial society that devalued such allegiances.

Nevertheless, the twenty papers selected for this article represent a wealth of information. They show the "reality of an existence"absent in the pages of school records, Department of Public Instruction (DPI) publications, and school officials' correspondence -in which students asserted their "resistant identities" and refused to be "objects of domination" tied to scripts associating whiteness to civilization and darkness to "savage "otherness." 17 As such, these essays reveal how Native Hawaiians imposed their own objectives, values, and expectations onto the islands' educational system and its Americanization efforts. Instead of emphasizing how students responded to specific policy initiatives, these writings focus on how students, their families, and communities refashioned assimilationist schooling to strengthen and maintain their cultural identity, obtain language proficiency, and, to the degree possible, determine their

${ }^{17}$ K. Tsianina Lomawaima, They Called It Prairie Light: The Story of Chilocco Indian School (Lincoln: University of Nebraska Press, 1995), 158; and Sengupta, "Elites, Subalterns, and American Identities," 1111. 
own future. To examine these sources is to move away from a policyoriented emphasis on passive assimilation to a student-oriented analysis of the ways in which young people, as agents of their own lives, in control of their own consciousness, responded to specific schooling agendas and actively pursued securing knowledge and skills to succeed and survive in an Americanized Hawai'i.

\section{Making Hawai'i American}

Once Hawai'i officially became "American" in 1898, white-settler policymakers set about employing the new territory's schools to enact a pedagogical campaign of erasure to legitimize US acquisition of the islands. They understood that allowing the Hawaiian national identity to persist threatened their nation-building efforts. As a result, white educators, politicians, and administrators designed educational programs to naturalize Hawai'i's student populations to nearly a century of Anglo-American intervention. Their goal: demonstrate that annexation represented a positive and inevitable development in America's benevolent march toward progress. This approach required eliminating memories of nineteenth-century US aggression, especially the 1893 overthrow and the dubious process leading to annexation, by presenting those events as the "necessary and fitting sequel to the chain of events" supporting the "incorporation of the Hawaiian Islands into the body politic of the United States," not as violating American values of freedom and democracy. According to President William McKinley, between 1820 and 1893, the Hawaiian government's "virtual dependence" on the "benevolent protection of the United States" upheld annexation as the "inevitable consequence" of the two nations" relationship. ${ }^{18}$ Thus, as the president succinctly put it, "Under such circumstances, annexation is not a change; it is a consummation."19

Contemporary statements by white-settler politicians and school officials support McKinley's view and suggest that Native Hawaiians happily cooperated in the assimilation process. David L. Crawford, president of the University of Hawai'i (1927-1941), argued that even before US annexation, Hawai' $i$ had always been on the path to becoming "American," as the "ambition of the Hawaiian people was to keep up to American standards in the development of their educational program." 20 The dean of the Territorial Normal School (1921-1947),

${ }^{18}$ John Roy Musick, Hawaii, Our New Possessions: An Account of Travels and Adventure (New York: Funk \& Wagnalls, 1898), 487-88.

${ }^{19}$ Musick, Hawaii, Our New Possessions, 489.

${ }^{20}$ David Livingston Crawford, Paradox in Hawaii: An Examination of Industry and Education and the Paradox They Present (Boston: Stratford, 1933), 192-93. 
Benjamin O. Wist, pointed to Native Hawaiians as willing participants in making the Americanization of Hawaiians a "success." Highlighting the "great socializing influence of the Hawaiian race" as an important "quality" in making the "Hawaiian a good teacher," he added that this "quality" helped render the "Americanization program possible." ${ }^{21}$ Finally, Wallace Rider Farrington, territorial governor (1920-1928) and publisher of the Honolulu Star-Bulletin, described the islands' public school system as the "greatest destiny controlling institution" for making Hawai' $i$ American. He believed the schools "must be so intensively and aggressively American" that the "children themselves will combat any alien influences that might substitute in their mature lives ... democratic Americanism." The schools were so successful in this regard, he held, that America had "ceased to worry over the Hawaiians." 22

Farrington and other white educators had good reason to believe Native Hawaiians had been pacified. For nearly a century, white settlers relied on their economic and political power to debilitate and "dismember" Native consciousness by removing and replacing Indigenous culture, language, and identity with Western civilization and white governance. ${ }^{23}$ Schools represented the perfect tool to fulfill this goal. They ensured the "consummation" of America's civilizing mission by eliminating examples of Hawaiian resistance and cultural identity through assimilation into the broader settler society. Anthropologist and ethnographer Patrick Wolfe theorized that this process was part of the larger project of settler colonialism. As one of a "range of strategies," assimilation represented a "more effective mode of elimination" that avoided a "disruptive affront to the rule of law." ${ }^{24}$ Rather than frontier homicide or apartheid policies, schooling promoted the "resocialization" of Natives by guiding their loyalties to the "egalitarian credentials" and "progressive individualism of the American dream." 25

Manual training in the public schools played an early critical part in this process. Beginning in the late 1840s, the Hawaiian kingdom's minister of education, Richard Armstrong, a former American missionary, began experimenting with a public educational system that

\footnotetext{
${ }^{21}$ Benjamin O. Wist, "Making School Teachers in Hawaii," Paradise of the Pacific 32 (Dec. 1921), 63.

${ }^{22}$ Wallace R. Farrington, "How Can the Schools Help Preserve SelfGovernment in Hawaii?," Hawaii Educational Review 21, no. 6 (Feb. 1933), 173, 183.

${ }^{23}$ For more about the history of white-settler colonialism in nineteenth-century Hawai'i, see Jonathan Kay Kamakawiwo'ole Osorio, Dismembering Labui: A History of the Hawaiian Nation to 1887 (Honolulu: University of Hawai'i Press, 2002).

${ }^{24}$ Patrick Wolfe, "Settler Colonialism and the Elimination of the Native," Journal of Genocide Research 8, no. 4 (Dec. 2006), 402.

${ }^{25}$ Wolfe, "Settler Colonialism," 400.
} 
combined industrial and agricultural training for boys and homemaking for girls with basic literacy skills in an effort to promote morality through physical labor. By the 1880s, white American school administrators further refined Armstrong's vision by creating a rudimentary curriculum that combined basic literacy and arithmetic with instruction in a trade to train Natives to be either laborers or teachers of industrial education. The goal was to create a racial underclass of "deferential, hard-working" laborers who accepted subservient roles in American society. ${ }^{26}$ This strategy served the interests of the white minority by preventing the Indigenous population from competing with local whites for leadership positions in government and industry. ${ }^{27}$

Territorial educators maintained this pedagogical approach into the twentieth century but faced new challenges. Large numbers of Asian students, whose parents had been brought to Hawai'i to work in the islands' sugar and pineapple plantations, now attended the public schools, stoking white fears of a growing "yellow peril" in the territory. To temper this anxiety, territorial politicians and school administrators attempted to convince skeptical whites both in Hawai' $i$ and on the continent that the territory was American. They touted schools as key assimilationist institutions for "creating citizens as well as workers." ${ }^{28}$ School officials explained how Hawai'i's schools introduced both progressive and humanitarian American ideals through democratic education (improving the "quality of life for all"), vocational training, and labor efficiency (producing a skilled workforce and increasing productivity). ${ }^{29}$ By instructing teachers to concentrate on American history, "free enterprise," and democracy to instill "100 percent Americanism," white educators also sought to root out the "backward" "alien" ways of Hawai'i's "dominantly darkskinned and slant-eyed" students. ${ }^{30}$ They argued that their Americanization process remained uninhibited by the continent's racism and "melted" Hawai'i's diverse cultures and ethnicities together into a homogeneous "indigenous American type" that ensured both "racial harmony" and a happy labor force. ${ }^{31}$

${ }^{26}$ Clif Stratton, Education for Empire: American Schools, Race, and the Paths of Good Citizenship (Oakland: University of California Press, 2016), 127.

${ }^{27}$ Beyer, "The Connection of Samuel Chapman Amstrong," 44, 47-48.

${ }^{28}$ Stratton, Education for Empire, 88, 94.

${ }^{29}$ A. J. Angulo, Empire and Education: A History of Greed and Goodwill from the War of 1898 to the War on Terror (New York: Palgrave Macmillan, 2012), xvi-xvii.

${ }^{30}$ Lawrence H. Fuchs, Hawaii Pono: A Social History (San Diego: Harcourt Brace Jovanovich, 1983), 282-83.

${ }^{31}$ Stratton, Education for Empire, 88; and Eileen Tamura, Americanization, Acculturation, and Ethnic Identity: The Nisei Generation in Hawaii (Urbana: University of Illinois Press, 1993), 49-50. 
Despite these noble claims, Hawai'i's schoolmen remained committed to limiting Native and Asian students' socioeconomic mobility. By combining policies of manual training, remedial education, and Americanization, they sought to produce a compliant workforce and docile citizenry that served the economic and political interests of Hawai'i's oligarchy. ${ }^{32}$ Their efforts "mushroomed" after World War I, as school officials feared the "Japanizing" of the territory due to the growing presence of Japanese laborers in the islands and Japan's aggressive expansion throughout the Pacific in the 1930s. Thus, during the interwar years, as the public routinely questioned the American patriotism of Issei (first-generation) and Nisei (second-generation) Japanese, white school bureaucrats devoted more and more time and energy to assimilating Hawai'i's Japanese population. ${ }^{33}$ As for Native Hawaiians, school officials had "ceased to worry" about them. ${ }^{34}$ They believed that Natives had been completely assimilated, thereby made into "effective Americanizers." ${ }^{35}$ As a result, school administrators touted them as the territory's model minority, highlighting their "great socializing influence" as a key quality for other nonwhite groups to emulate on their path to American citizenship. ${ }^{36}$ But how accurate was this depiction of "success" in Americanizing Native Hawaiians?

\section{"Turning the Power": Locating Resiliency through Student Stories}

Native American boarding schools, according to Clifford Trafzer, Jean Keller, and Lorene Sisquoc, represented a "successful failure" in Americanizers' efforts to assimilate Indian students and destroy the foundational "essence" of their culture and identity. ${ }^{37}$ While the schools provided Native students with an academic and vocational education-saturated with American values of domesticity, consumerism, and rugged individualism-Native students and their families "turned the power" by imbuing their education with their own positive meanings. They converted the destructive cultural environment of the boarding schools into a constructive learning space for their own

${ }^{32}$ Stratton, Education for Empire, 88-89.

${ }^{33}$ Tamura, Americanization, Acculturation, and Ethnic Identity, 56-61.

${ }^{34}$ Farrington, "How Can the Schools Help Preserve Self-Government in Hawaii?," 173.

${ }^{35}$ Michelle Morgan, "Americanizing the Teachers: Identity, Citizenship, and the Teaching Corps in Hawai'i, 1900-1941," Western Historical Quarterly 45, no. 2 (May 2014), 154.

${ }^{36}$ Wist, "Making School Teachers in Hawaii," 63.

${ }^{37}$ Trafzer, Keller, and Sisquoc, "Origin and Development of the American Indian Boarding School System," 2. 
purposes, such as obtaining skilled employment, English-language proficiency, and new knowledge that would enable them to assert and protect Native claims and cultural identity in white society. Their efforts represented a pragmatic approach to white education, viewing it as a "means to an end." 38

This acknowledgment of the importance of American schooling did not mean accepting the white ways as superior. Rather, Native families and tribes began to realize that to succeed in the white world their youth needed to learn how to integrate "alien customs" into Native "lifeways." 39 While the white "architects of assimilation" expected Indian children to abandon their cultural and tribal ties and "learn to talk and work like Americans," these outcomes never materialized. ${ }^{40}$ Indian boarding-school students, as Native anthropologist K. Tsianina Lomawaima explains, maintained a "stubborn refusal" to relinquish their Indigenous identity. ${ }^{41}$ They "turned assimilationist logic on its head" and converted boarding schools and the Americanizing curriculum into "vehicles for cultural survival," demonstrating they could talk and work like Americans without becoming American. ${ }^{42}$ These examples of student resiliency provide a more nuanced and complicated understanding of how students negotiated the ways schools and white society pressured them to assimilate. By defining themselves through their achievements, creating intertribal social networks, and gaining competencies in various subjects useful for survival in white society, Native students asserted their abilities to innovate and resist. ${ }^{43}$

This understanding of resiliency offers an effective means for conceptualizing how Native Hawaiian students responded to assimilationism. Territorial public schools were not federal institutions like the boarding schools that aimed to achieve "education for extinction" in the $1870 \mathrm{~s} .{ }^{44}$ Native Hawaiians were not subjected to the same physically traumatic experiences as Native Americans: forced removal to

${ }^{38}$ Vučković, Voices from Haskell, 241.

${ }^{39}$ Vučković, Voices from Haskell, 241; and Thomas G. Andrews, "Turning the Tables on Assimilation: Oglala Lakotas and the Pine Ridge Day Schools, 18891920s," Western Historical Quarterly 33, no. 4 (Dec. 2002), 430.

${ }^{40}$ Andrews, "Turning the Tables on Assimilation," 425.

${ }^{41}$ Lomawaima, They Called It Prairie Light, xii, 99.

${ }^{42}$ Andrews, "Turning the Tables on Assimilation," 425, 427.

${ }^{43}$ Amelia V. Katanski, Learning to Write "Indian": The Boarding-School Experience and American Indian Literature (Norman: University of Oklahoma Press, 2006), 2-17; and Melissa D. Parkhurst, To Win the Indian Heart: Music at Chemawa Indian School (Corvallis: Oregon State University Press, 2014), 189, 19.

${ }^{44}$ For more on American schooling and Native American cultures, see David Wallace Adams, Education for Extinction: American Indians and the Boarding School 
government boarding schools, military discipline, or twenty-fourhour observation. Nevertheless, they shared strikingly similar experiences. The repression of Indigenous language and culture, subjection to a foreign curriculum, denial of their cultural heritage and history, and the unequal balance of power between oppressor and oppressed experienced in schools and society represented common occurrences highlighting their mutually painful past. And, like their American Indian counterparts, Native Hawaiians also subverted their colonial schooling by defying the goals of white authorities and imposing their own.

\section{Going to School}

In stories from schools across the territory, Native students repeatedly emphasized the importance of obtaining a good education to ensure a secure future. They understood that success at school could pave a path to white-collar employment as stenographers, social workers, clerks, secretaries, nurses, lawyers, doctors, and teachers. One Native student said as much when he wrote, "Hawaiian-born children of my group are attending schools and educational institutions for the benefit of their lives." ${ }^{45}$ Mixed in with their optimism, Native students consistently worried about the future of their people. Another student lamented that "everytime" she thought about her people, she felt a "pang of regret that these islands were ever discovered." Her words captured the grim and poignant reality of Hawaiians, who never envisioned that "someday there $[\mathrm{sic}]$ lands would be taken from them," or "shoved toward the 'outside' districts." Still, despite the gloom, like so many other Native students, this girl expressed hope for the future, believing that, through public education, "Hawaiian children are now being taught how to help their people." ${ }^{46}$

In many autobiographies, Native Hawaiian students describe a collective awareness that personal success as students could help their families. They espoused a strong communal sense of responsibility and duty to improve the quality of life for their families and communities. Thus, they believed their drive to succeed and benefit from an American education would provide benefits for the wider community.

Experience, 1875-1928 (Lawrence: University Press of Kansas, 1995); Child, Boarding School Seasons; and Lomawaima, They Called It Prairie Light.

${ }^{45}$ McKinley High School Respondent 152, reel 15, 1-2, Life Histories of Students: Selected Series, William Carlson Smith Papers [microfilm], Hamilton Library, University of Hawai' $i-M a ̄ n o a$, Honolulu, HI (hereafter Life Histories). The original manuscripts and typescript transcripts are held by Special Collections, University of Oregon Library, Eugene, OR.

${ }^{46}$ Respondent 60, Hilo High School, reel 4, 2, 11, Life Histories. 
This sense of purpose and dedication appeared most often in essays by students considering a career in education, and for good reason.

For many aspiring teachers, the plight of their people drove them to act. One student from Hilo bluntly stated, "I must devote myself to do work for my community instead of helping myself only." 47 Fearing Hawaiians "gradually fading into the past," another described his "duty" to give everything within his "power for the rehabilitation of [my] race." 48 One particular "daughter of the soil," worrying about her race "dying out" in the face of low life-expectancy rates, high unemployment, and disproportionately high incidences of cancer, alcoholism, diabetes, tuberculosis, measles, influenza, and chicken pox, expressed her frustration that Hawaiian children were "left stranded of many positions" and opportunities to succeed due to the "excess of Orientals" in the schools. ${ }^{49}$ She also recognized how immigrant children benefited from active participation in the school system, and she wanted the same for her people, explaining, "I am sure Hawaiian students may be bright also if they put more interest in their studying." She thus sought to "contribute [her] part to [their] benefit" by becoming a teacher, a common aspiration..$^{50}$

While an admirable goal, becoming a teacher would not be easy. In 1926, the DPI managed 187 elementary, intermediate, and secondary schools; employed 2,145 teachers; and educated 72,574 students across the Hawaiian Islands. ${ }^{51}$ While the total number of students and teachers rose throughout the 1920s, the number of Native Hawaiians in both categories steadily declined. In 1920, Native students made up 18 percent of the total student population but dipped to 10 percent by 1930 . This slip was also noticed among Hawaiian normal-school students, as their numbers dropped from 30 percent at the beginning of the decade to 21 percent ten years later. One reason for this shift was increasing numbers of Japanese school-age children and naturalized adults legally able to teach. ${ }^{52}$ For in-service Native teachers, their numbers started out at 33 percent in 1920 but slid to 21 percent by $1930 .^{53}$

${ }^{47}$ Respondent 192, Hilo High School, reel 2, 5, Life Histories.

${ }^{48}$ Respondent 255, Hilo High School, reel 3, 3, Life Histories.

${ }^{49}$ Respondent 40, Hilo High School, reel 5, 3-4, Life Histories; Chronic Disease Disparities Report 2011: Social Determinants (Honolulu: Hawai'i State Department of Health, June 2011); and US Census Bureau, Mortality Statistics 1931 (Washington, DC: Government Printing Office, 1935), 470-74.

${ }^{50}$ Respondent 40, 3-4.

${ }^{51}$ Robert C. Schmitt, Historical Statistics of Hawaii (Honolulu: University of Hawaii Press, 1977), 214.

${ }^{52}$ Morgan, "Americanizing the Teachers," 157.

${ }^{53}$ Thayne M. Livesay, A Study of Public Education in Hawaii: With Special Reference to the Pupil Population (Honolulu: University of Hawaii, 1932), 76-77; United States 
Nevertheless, between 1900 and 1930, Native Hawaiians entered the Territorial Normal School in droves and averaged nearly a quarter of the overall teacher workforce. By 1929, they represented the largest nonwhite racial group employed by the DPI, as well as the largest group of graduates from the school, "even outnumbering Orientals." ${ }^{54}$ Motivated and determined, many made it clear why they chose this profession: they wanted to be a "great help" to their communities and make the "younger Hawaii ... the best they can be." ${ }^{55}$ One ambitious student-teacher equated her future position to a "great leader in a community, solving problems for the people and helping them." This sentiment was exceptionally strong when she thought of her "Hawaiian nation ... dying out." Believing "I must do something," she dedicated her "future here in Hawaii" to obtaining an advanced degree in curriculum development from a mainland university after teaching for a few years. Her ultimate goal was to become a "specialist in reading and storytelling" and return home to provide Native students with a "proper education." 56

Native Hawaiians choosing teaching careers in a school system intent on assimilation may have seemed like an odd choice. As Michelle Morgan points out, American education was an "integral part" of America's empire. ${ }^{57}$ Classrooms represented intimate spaces of Americanization, where white American educators (mostly women), trained on the continent, and nonwhite island-born teachers, trained at the Territorial Normal School, facilitated students' acceptance of the English language and prepared them for American citizenship. However, nonwhite teachers were not mindless automatons. Morgan argues that while many of the territory's racially diverse teachers toed the line on several assimilationist policies, they also enforced their core belief on the importance of education: social mobility. ${ }^{58}$ They insisted on schools providing educational opportunities for student success and challenging students to think critically about their world, rather than simply funneling them into employment on the plantations. ${ }^{59}$

Office of Education, A Survey of Education in Hawaii (Washington, DC: Government Printing Office, 1920), 144-45; and Riley H. Allen, "Education and Race Problems in Hawaii," American Review of Reviews 64 (Dec. 1921), 613-24.

${ }^{54}$ Ruth Cornelia Shaw, "The Output of the Territorial Normal and Training School." (master's thesis, University of Hawaii, 1929), 25-30, 104.

${ }^{55}$ Respondent 258, Territorial Normal School, reel 5, 11, Life Histories; and Respondent 239, Territorial Normal School, reel 6, 7, Life Histories.

${ }^{56}$ Respondent 195, Territorial Normal School, reel 6, 7-8, Life Histories.

${ }^{57}$ Morgan, "Americanizing the Teachers," 148.

${ }^{58}$ Morgan, "Americanizing the Teachers," 165.

${ }^{59}$ Morgan, "Americanizing the Teachers," 166-67. 
Emboldened and encouraged, numerous Native Hawaiian public school students pursued their education with the belief that success in school would make a difference both for themselves and their communities. From their writings, they exhibited a clear and strong sense of purpose that success at school increased the chances of a productive and positive future, not only for themselves but for their families and communities. Yet students did not embark on this journey alone. Underwriting their beliefs and supporting their studies, Native families operated behind the scenes, building a solid home environment for their children to engage their American schooling and still retain their Native identity.

\section{Behind the Scenes: Families and Teachers}

Native families played a key role in encouraging and affirming their children's engagement with the American educational system. Their supportive influence reinforced a constructive and pragmatic understanding that survival in an Americanized Hawai'i required active participation at school. Throughout their autobiographies, students constantly referred to their parents' and grandparents' efforts to make education a priority. Whether they moved from their rural homes to urban areas (mostly Hilo and Honolulu) for greater access to educational opportunities, their parents often prevented them from taking on part-time work lest it hurt their studies, lectured them on the need to learn English, joined the PTA, or simply helped out with their homework. Native families invested time, resources, and energy to help ensure a successful future for their children. They were not "selling out." Instead, they viewed American schooling as a necessary investment for promoting their children's chances of socioeconomic advancement.

This complex history of engagement and exchange with nonHawaiian societies resembles the historical experiences of American Indians and white settlers on the continent. For nearly three hundred years, Native Americans negotiated, adapted, and resisted European and white-settler colonialism across North America. From these encounters, Native tribes "absorbed knowledge" as part of a rational approach of incorporating new learning into their cultural systems. Whether they acquired new languages, literacy, agricultural advancements, equestrianism, artistic designs, or technological advancements (firearms, iron), American Indians demonstrated a pragmatic willingness to "grow, adapt, adopt, and expand their ways of knowing." 60

${ }^{60}$ Trafzer, Keller, and Sisquoc, "Origin and Development of the American Indian Boarding School System," 4-5. 
These tools and skills allowed them to assert their identity, interests, and physical presence, demonstrating how Native survival itself became a "primary act of resistance." 61

This understanding does not erase the enforced poverty, broken treaties, and often violent relocation and loss of land, as well as death, that accompanied the Native experience with Europeans, all in the name of "progress." Instead, including survival as a form of resistance helps show how the overuse of "extermination" as a historiographical theme has contributed to a problematically passive and "tidy narrative" describing how Native Americans were "essentially eliminated." 62 Overemphasis on the theme of extermination "eliminates" any analysis that makes "indigenous persistence ... as important as resistance," thus recognizing only true opposition as acts of "'doomed' physical resistance." 63 As Joy Porter notes, survival required the "maintenance, often against terrific odds, of the web of social, familial, political, and cultural platforms" that made other forms of resistance possible. ${ }^{64}$ Thus, for Native American parents, the "redeeming value" of sending their children to boarding schools was the educational opportunity it provided to secure the necessary survival "platforms" to resist assimilation. ${ }^{65}$

Understanding how American Indians faced and engaged settler colonialism provides an important framework for conceptualizing how Native Hawaiians also prioritized learning as a rational means to survive. Throughout the nineteenth century, Hawaiians learned how to incorporate Western skills and ideas on government, literacy, technology, institutions, and white people into their political systems. They in turn used these foreign systems to advance their interests and ensure their survival in an era of increasing foreign encroachment. ${ }^{66}$ Even

${ }^{61}$ Joy Porter, "Progressivism and Native American Self-Expression in the Late Nineteenth and Early Twentieth Century," in Native Diasporas: Indigenous Identities and Settler Colonialism in the Americas, ed. Gregory D. Smithers, Brooke N. Newman, Pekka Hämäläinen, and Paul Spickard (Lincoln: University of Nebraska Press, 2014), 293.

${ }^{62}$ Gregory D. Smithers, “'What Is an Indian?'-The Enduring Question of American Indian Identity," in Smithers et al., Native Diasporas, 6.

${ }^{63}$ Porter, "Progressivism and Native American Self-Expression," 273-74.

${ }^{64}$ Porter, "Progressivism and Native American Self-Expression," 274.

${ }^{65}$ David Wallace Adams, "Beyond Bleakness: The Brighter Side of Indian Boarding Schools," in Trafzer, Keller, and Sisquoc, Boarding School Blues, 36.

${ }^{66}$ Trafzer, Keller, and Sisquoc, "Origin and Development of the American Indian Boarding School System," 4-5. For more on various Hawaiian responses, see Noenoe K. Silva, Aloha Betrayed: Native Hawaiian Resistance to American Colonialism (Durham, NC: Duke University Press, 2004); Stuart Banner, "Preparing to Be Colonized: Land Tenure and Legal Strategy in Nineteenth-Century Hawaii," Law and Society Review 39, no. 2 (June 2005), 273-314; and Frank 
prior to Western contact in 1778 , Native Hawaiians were not culturally "static." Mele (songs and chants) and mo'olelo (legends and stories) recount a voyaging period during which numerous round-trip journeys between Hawai'i and "Kahiki" facilitated the exchange of ideas, language, culture, trade, navigation, and technology. They also describe how ali'i (chiefs) on both sides of these exchanges used intermarriage to establish and maintain political alliances between distant lands. ${ }^{67}$

For Native parents, participating in the public school system fits within this longue durée. With an American education, they sought opportunities for their children to "absorb knowledge" as part of a larger effort to advance their individual and familial interests, resist colonization, and prepare for a better future. Like many of their late nineteenth-century American Indian counterparts, Native Hawaiian families often did not promote engagement with the schools expecting students to lose their cultural identity. Instead, going to school offered the chance to obtain language skills and "white ways" in order to guide and assist their survival as Natives. While the loss of language and culture remained a constant worry, many families expressed a greater fear of their children being left behind academically and financially to face an uncertain future as Hawai'i Americanized. Underwriting this Native anxiety was the sense that parents wanted the best for their children and did not hesitate to let them know that education would play a key role in their success as Hawaiians.

Family support also came at important moments in students' lives when they questioned the need to continue their education. Some students merely gave a nod of acknowledgment, as one explained, "Many years after I was in school I realized the importance of an education. After graduating from Grammar School my intention was then to work but father said I ought to continue and go to High School." ${ }^{68}$ Others expressed a bit more of their gratitude, as a self-described "Tom boy" explained:

\footnotetext{
J. Karpiel Jr., "Mystic Ties of Brotherhood: Freemasonry, Royalty, and Ritual in Hawaii," Pacific Historical Review 69, no. 3 (Aug. 2000), 357-97."

${ }^{67}$ Rowland B. Reeve, Na Wabi Pana O Kaho'olawe= The Storied Places of Kaho'olawe: A Study of the Traditional Cultural Places on the Island of Kabo'olawe (Wailuku, HI: Kaho'olawe Island Conveyance Commission, 1993), 163-64; and Patrick Vinton Kirch, On the Road of the Winds: An Archaeological History of the Pacific Islands before European Contact (Berkeley: University of California Press, 2002), 291. "Kahiki" once referred to the island of Tahiti but eventually shifted to a general idea of lands far away.

${ }^{68}$ Respondent 158, Hilo High School, reel 2, 2, 3, Life Histories.
} 
During my eighth grade year, I had no intention of going to high school because I wanted to work. I wanted to take up a business course to become a stenographer because my mother had taught me typewriting and with this little start I wanted and was interested in office work but my mother insisted on my attending high school. I consented and now I am thankful. One reason for my being thankful is because the girl friends with whom I associated preferred married life to education. ... If I had not left Maui, I would probably have followed their footsteps. ${ }^{69}$

Students identified their families as the most powerful influence on their decisions to continue their studies. In their autobiographies, many described how their parents went out of their way to give them their "utmost" in providing "ample time to study." 70 Students also noted how parents "boosted" their children's spirits when faced with "many difficulties" over their schoolwork, offering emotional support and even tutoring various subjects. ${ }^{71}$ One student not only benefited from parental encouragement but also received support from her older siblings, who always remained "interested in my school work" and tried to assist her "as much as possible."72

Such support often contributed to developing students' "duty to help." As one student put it, his family was "always helping me to become successful. This has given me sympathy and courage to go through school and ... earn enough money to support myself and my parents." ${ }^{73}$ Another saw parental influence on a larger, community-wide scale, commenting how "parents are helping many young people by sending them to schools" and how this active involvement produced positive results:

The Hawaiian-born children of my racial group are trying hard to get a good education. They are willing to get out of school and work for themselves. When they are earning there $[$ sic $]$ own living they help there $[s i c]$ parents. In this way they make there $[$ sic $]$ parents feel happy. They also think that it was worth while $[$ sic $]$ sending there $[$ sic $]$ children to school. ${ }^{74}$

Indeed, active parental involvement in children's education occurred regardless of the parents' educational background. Parents who graduated from high school and even attended college wanted their children to receive "every educational opportunity possible" in

\footnotetext{
${ }^{69}$ Respondent 221, Territorial Normal School, reel 5, 2-3, Life Histories.

${ }^{70}$ Respondent 60, 5,

${ }^{71}$ Respondent 250, Hilo High School, reel 3, 3, Life Histories.

${ }^{72}$ Respondent 414, McKinley High School, reel 15, 4, Life Histories.

${ }^{73}$ Respondent 122, McKinley High School, reel 14, 6, 8, Life Histories.

${ }^{74}$ Respondent 359, McKinley High School, reel 15, 4-5, Life Histories.
} 
an effort to replicate their positive school experiences. ${ }^{75}$ As a university student named "Pauline" described, "Our parents, being educated, realize the value of education and have always urged us to take advantage of the opportunities afforded us." 76 This perception of the value of education was not limited to well-educated parents. In many cases, Native parents born and raised in rural districts, often with only an elementary school education (or less), sought to ensure that their children obtained the educational opportunities they never received. As one student observed, the parents of his community wanted to "solve their children's educational problems by belonging to the P.T.A" in order to afford them a "better education than they themselves were able to obtain." 77

However, while parents clearly held a vested interest in their children's success, they were not the only ones. Sympathetic teachers often augmented familial support as part of a united push for Native education. A number of students regarded Native Hawaiian educators as positive role models who challenged them to excel in their studies and provided encouragement to advance their schooling, not only for the students' own sake but also for the sake of their communities. A normal-school student told the story of her "excellent" elementary school teacher in Hāna, Maui, who "influenced [her] several times to study harder and become a teacher so that I could come right back and teach in the country." ${ }^{17}$ Another spoke of how a Native married couple, both teachers, "did everything to encourage" her to perform well at school. Affectionately called "Auntie Norah" and "Uncle Wilbur," these educators urged her to become a teacher herself. Having "not regretted taking this step," she finished high school, soon enrolled at the Territorial Normal School, and was "ready to begin real teaching." She also held high "hopes of going away to specialize" in an advanced degree on the continent. ${ }^{79}$

Student recognition of the positive influences of Native teachers and parents on their academic pursuits demonstrated how the Native community saw schooling as a means for success. This acknowledgment did not mean they accepted and condoned Americanization; rather, they viewed schooling as a vehicle for achieving socioeconomic stability in an uncertain time-even if this strategy came at a price. For Native Hawaiians, establishing a stable and productive future within Hawai'i's white settler-colonial society required adopting the socially

\footnotetext{
${ }^{75}$ Life History of Pauline Gleason, reel 2, 1, Life Histories.

${ }^{76}$ Life History of Pauline Gleason.

${ }^{77}$ Respondent 152, 5-6.

${ }^{78}$ Respondent 197, Territorial Normal School, reel 6, 9, Life Histories.

${ }^{79}$ Respondent 258, 5,8.
} 
and economically vital, but culturally caustic, tool of survival: the English language.

\section{The Survival Tool}

Following the arrival of British naval captain James Cook in 1778, Native Hawaiians quickly learned the importance of English-language literacy. The growing influx of English-speaking merchants, whalers, military personnel, and foreign diplomats in the early nineteenth century symbolized Hawai'i's participation in global networks of trade and international relations. In response, many high-ranking ali $i$ sent their children to the Hawaiian Chiefs' Children's School in preparation for roles as either $m \bar{o} \grave{\imath}$ (ruling monarch) or upper-level government positions. ${ }^{80}$ Built by Kauikeaouli (Kamehameha III) in 1840, the school prepared young ali' $i$ to be the future rulers of Hawai' $i$ by learning English and studying the ways of other "enlightened nations" in order to survive as an independent country within a Westernizing Pacific. ${ }^{81}$ Numerous maka'āinana (commoners) also sought and obtained English-language proficiency, either from their time as laborers or sailors on foreign ships or from regular contact with the islands' small population of English-speaking residents. ${ }^{82}$ Yet as Hawaiians prepared to engage with the outside world, foreigners in the islands had other plans.

By the 1880s, a small group of white sugar planters and American businessmen controlled the economy and held positions in the kingdom's legislature and cabinet. Despite the achievements of Native monarchs in modernizing the kingdom's infrastructure, securing international recognition of their national sovereignty, developing a profitable plantation economy, and cultivating a highly literate Indigenous population, this white minority considered Natives and their nation as inferior and backward. They perceived the resurgence of Hawaiian nationalism, cultural arts (hula), and Native-centric organizations (Hale Nauā), under the banner of "Hawai' $i$ for Hawaiians," as both threats to white control of government, commerce, and land ownership and confirmation of Native degeneracy. According to this "haole-formulated discourse," the Hawaiian nation was "naturally doomed," and its people needed to prepare for new lives under American

${ }^{80}$ Osorio, Dismembering Labui, 116.

${ }^{81}$ Kaomea, "Education for Elimination in Nineteenth-Century Hawai'i, 124; and Albert J. Schütz, The Voices of Eden: A History of Hawaiian Language Studies (Honolulu: University of Hawai'i Press, 1994), 298."

${ }^{82}$ Schütz, The Voices of Eden, 289-92. 
stewardship. ${ }^{83}$ A necessary first step: replacing the Hawaiian language with English.

Schools represented a critical institution for implementing and enforcing this transition. During the final years of the monarchy (1795-1893), white educators actively undermined the use of Hawaiian at both private and public schools. At the all-Native Hawaiian Kamehameha Schools, the board of trustees and Principal William Oleson forbade using the Hawaiian language on school grounds. By the early 1890s, the North Pacific Missionary Institute began transitioning the language of instruction from Hawaiian to English for students preparing to become missionaries. Even the kingdom's Board of Education (dominated by missionary descendants) sought to reduce the amount of Hawaiian-language public schools by shifting financial support to increase the number of English-language schools. While these policies failed to completely eliminate the Hawaiian language, they limited its use in the public sphere. They also stunted the spread of the language and the number of fluent speakers by restricting the opportunities for both Native students and foreigners to learn Hawaiian at school. ${ }^{84}$ Thus, the swift decline of Hawaiian-language schools during the late nineteenth century resulted not from growing Indigenous interest in English-language schools but from a "concerted government policy of neglect and opposition" by white settlers toward 'ōlelo Hawai'i (Hawaiian language). ${ }^{85}$

This neglect soon turned hostile, as political events in the 1890s quickly sealed the fate of the Hawaiian language. Queen Lili'uokalani's overthrow in 1893 by white "revolutionaries" and the establishment of a white-minority government (the Republic of Hawaii, 1893-1898) created friendly political conditions for the passage of Act 57 (1896), which reorganized the public school system and, under section 30, established English as the "medium and basis of instruction" for all private and public schools. ${ }^{86}$ Any institutions failing to comply with the Act faced losing DPI accreditation and financial support. ${ }^{87}$ American officials at the DPI, who were granted complete control of all affairs related to public instruction, including the ability

${ }^{83}$ Osorio, Dismembering Lahui, 176-81, 190-92, 208-9, 225-26.

${ }^{84}$ William E. H. Tagupa, "Education, Change, and Assimilation in Nineteenth Century Hawai' i," Pacific Studies 5, no. 1 (Fall 1981), 66-68; and Schütz, The Voices of Eden, 349-55.

${ }^{85}$ Tagupa, "Education, Change, and Assimilation," 68.

${ }^{86}$ Laws of the Republic of Hawaii Passed by the Legislature at its Session, 1896 (Honolulu, Hawaiian Gazette Company's Print, 1896), 186.

${ }^{87}$ Tagupa, "Education, Change, and Assimilation," 67. 
to "regulate the course of study to be pursued in all grades of public schools," all but ensured the Hawaiian language's demise. ${ }^{88}$

This effort to make English the de facto lingua franca exposed the extent to which Hawai'i's white elites at the turn of the twentieth century used education policy to assimilate Native Hawaiians into an American ethos. As the dominant ethnic group in the islands, Native Hawaiians represented the greatest organized political obstacle to white-minority rule and the goal of US annexation. ${ }^{89}$ Designed under this context, section 30 of Act 57 was not just about replacing official mediums of instruction, it was about subverting the cultural core of Native identity to neutralize Native Hawaiians as a political threat.

Many contemporary Native Hawaiians place great emphasis on section 30 as the root cause for the demise of their language, culture, and way of life. Certainly a powerful influence, this understanding of the Act oversimplifies the era's historical complexity and nuances by presuming that Native Hawaiians remained passive victims lacking any influence or control over their future. In reality, Natives faced tough choices about their economic, political, and cultural outlooks, and adopting the English language represented a painful but critical decision. This was not an easy choice, and it cannot be framed simply as capitulating to white supremacy or "selling out." Instead, like American Indians, Native Hawaiians "reinvented the enemy's language" for their own uses. ${ }^{90}$ While historian Michael C. Coleman warns against overusing the "triumphalist empowerment" argument, portraying the "erstwhile victim as now the near-controller" of a colonizer-colonized experience, in myriad ways Native Hawaiians successfully navigated the imposition of English in the Americanized school system and in this way-and somewhat paradoxicallyacquired an important tool for preserving their Hawaiian identity. ${ }^{91}$ As student autobiographies illustrate, the Native response to English-language acquisition was anything but simple.

Students' life histories complicate the singular view that the DPI was solely responsible for the decline of 'ōlelo Hawai' $i$ in the public

\footnotetext{
${ }^{88}$ Laws of the Republic of Hawaii Passed by the Legislature, 189.

${ }^{89}$ Lauren L. Basson, "Fit for Annexation but Unfit to Vote? Debating Hawaiian Suffrage Qualifications at the Turn of the Twentieth Century," Social Science History 29, no. 4 (Winter 2005), 575-98; Osorio, Dismembering Labui; Silva, Aloha Betrayed; and Noenoe K. Silva, "I Kū Mau Mau: How Kānaka Maoli Tried to Sustain National Identity within the United States Political System," American Studies 45, no. 3 (Fall 2004), 9-31."

${ }^{90}$ Katanski, Learning to Write "Indian," 6.

${ }^{91}$ Michael C. Coleman, "The Symbiotic Embrace: American Indians, White Educators and the School, 1820s-1920s" History of Education 25, no. 1 (March 1996), 17.
} 
sphere. The stories of Hawaiian youth reveal a decision among Hawaiian families to employ seemingly extreme measures to secure a better future for their children. This impulse informed their conscious decision not to teach or speak the Hawaiian language at home and instead replace it with English. Like Indian families who struggled with a similar linguistic "crisis," no single factor influenced Native parents' decisions but rather a "host" of social, political, and economic pressures led them to embrace, or at least accept, using English at home and in public. ${ }^{92}$ Many believed that surviving and prospering in an Americanized Hawai'i required proficiency in English and that practicing their native tongue only hampered their children's chances for success. Faced with an uncertain future, Native Hawaiian parents adopted the English language as a necessary tool for survival.

In their life histories, students explain why their parents chose not to speak to them in Hawaiian. The father of a Native female university student named Ernie told her grandmother that his "native tongue ... was very seldom heard in the house" because Ernie was "having a hard time learning to speak English correctly." ${ }^{93}$ In another instance, Pauline's father wanted to maintain a high level of Hawaiian-language proficiency, even though her mother did not understand Hawaiian and the family spoke only English. However, this was not the mother's fault. Pauline's grandparents had deliberately chosen not to speak Hawaiian to her mother and her siblings as they grew up, believing that the "English language would be THE language and that the learning of their native language would make it harder for them to learn English." As a result, her mother never learned to speak Hawaiian. ${ }^{94}$

Other student stories contain more nuanced discussions of their families' appropriation of English as a survival tool. One student whose parents were both Native 'ōlelo Hawai'i speakers described how they naturalized the use of English at home despite their limited comprehension. As she explained, "I must admit that my mother does not speak English very fluently, but in teaching me to speak it from babyhood, she established quite a good foundation for my school life in the grammar grades." 95 Another expressed how her grandfather, a former teacher at a Hawaiian school on Maui, "realized the importance and advantage of speaking English as he was neglected of that privilege

\footnotetext{
${ }^{92}$ Teresa L. McCarty, A Place to Be Navajo: Rough Rock and the Struggle for SelfDetermination in Indigenous Schooling (Mahwah, NJ: Lawrence Erlbaum Associates, 2002), 65, 181.

${ }^{93}$ Respondent 41, University of Hawai'i-Mānoa, reel 1, 1, Life Stories.

${ }^{94}$ Life History of Pauline Gleason, 1.

${ }^{95}$ Respondent 256, Hilo High School, reel 3, 1, Life Histories.
} 
during his younger days." Despite his rudimentary language skills, she noticed how he used English to assist him in dealings with prominent haole, who eventually paid his sons' tuition to attend private schools on $\mathrm{O}^{\prime}$ ahu. Impressed, she worked for a haole family during her summer vacations, realizing that the "more I come in contact with them the better I can improve my English." 96

These student experiences capture a difficult choice for members of the Native Hawaiian community. Facing a deluge of outside interests and people reshaping the cultural, social, and demographic fabric of the islands, Hawaiian families faced a seemingly impossible dilemma: save their language or save their children. Witnesses to the mushrooming of America's presence and the English language in the islands, Native parents and grandparents were forced to reconcile the uncompromising demands of Americanization with their imperiled cultural values and being. Student stories provide rare insight into how these families wrestled with the bleak reality that the English language and American power were not going away. They establish the Native Hawaiian world view of prioritizing English proficiency over their own language, not as a means of assimilation but as a means of resisting marginalization and asserting the possibility of controlling their own future.

Embedded in students' autobiographies were complaints about their elders' strategy to unilaterally deny them their Indigenous language. Many students disagreed with the English-language focus of their families and communities. They expressed disappointment and irritation at their families' overzealous (but arguably well-intended) decision to learn English at any cost rather than advocate for the return of Hawaiian-language schools or promote using Hawaiian at home and English at school. Many students expressed embarrassment at their inability to respond fluently when spoken to in Hawaiian and vented their frustration at the lack of opportunities to learn their language either at home or at school. However, students did more than just complain: many expressed confidence in their abilities to successfully engage Americanization and adopt English while also preserving their cultural identity.

Ernie's story effectively illustrates this strategy. Writing in the third-person, Ernie credited her father with fostering her interest "in things Hawaiian" and wanting to learn the language. She explained if her father, Mr. Mara, "hand't [sic] been educated to American ideals and standards and kept up with time, Ernie might have found herself balked $[$ sic $]$ at any such attempt." Both of her parents regularly "looked over her report card with the greatest care, but there was little they

\footnotetext{
${ }^{96}$ Respondent 197, 4, 8.
} 
could find that displease[d] them." Such affirmation of the effects of their daughter's American schooling reflected how many Native students viewed their education on their own terms-independently of white colonial administrators' assimilationist agenda. Ernie wanted an English-language education to make her own life better, at least in material terms. To Ernie, "It has always seemed to me that we were just as good as the haole's $[s i c]$ and that our family life was the same as in the Average American home." ${ }^{97}$ This syncretic adaptation of English-language instruction in Hawai'i's public schools showed how Native families played a critical role in maintaining students' cultural identity while supporting their educational development. Ernie's parents created a positive home environment that valued education and instilled cultural pride. They extended their own English-language education experiences to Ernie, fostering a general appreciation for "absorbing knowledge"-knowledge that included both her Native heritage and American education-while also nurturing her pride and "interest in things Hawaiian." 98

Not all students were as fortunate. Many who lacked such parental involvement expressed a desire for the public schools to teach the Hawaiian language. One Hilo High School student recognized that English "counted more than anything else" and committed herself to improving her language skills by going to the library and getting together with "haoles" to practice speaking "good English." But not once did she reject her Native identity or abandon her heritage. While acknowledging the importance of English, she also expressed clear interest in her native language, explaining, "If there was a school for Hawaiians ... I would go, for I want to be able to speak and write my native language." 99 Another Hilo High student shared similar frustrations over the "lackness" of her mother tongue despite her parents being "well learned in it." While claiming to "understand [Hawaiian] well," she described her ability to speak as "very little and brokenly." Disappointed, but motivated to learn, she planned to "study Hawaiian in the schools of Honolulu" and expressed a fervent "wish that the Hawaiian language would be taught in every school of the territory." Believing that her language's survival was of "vital importance" to Hawaiians of all generations, she called on the islands' public schools to address the interests of her community. ${ }^{100}$

\footnotetext{
${ }^{97}$ Respondent 41, 2-3.

${ }^{98}$ Respondent 41, 3.

${ }^{99}$ Respondent 192, 2-4.

${ }^{100}$ Respondent 40, 4.
} 


\section{Education and Race}

Clearly, many Native students maintained their Indigenous identities despite the goals of Americanization. While denied the opportunity to learn their language at school and relentlessly exposed to an assimilationist curriculum, student autobiographies show that many students continued to see themselves as Native Hawaiian. This sentiment only grew stronger and more pronounced when students specifically addressed Hawai'i's "color line." In their life histories, Native youth shared their candid assessments about the hypocrisy of Americanizers preaching equal opportunity in a nation that practiced racial discrimination. As such, they demonstrated an acute awareness of the "ironic doubleness" of being an American-educated Hawaiian youth. They recognized the disparity between learning the exceptionalist rhetoric of color-blind democracy as American students in the public schools and living the reality of their racialized treatment by haole as Native Hawaiians, and they redirected and articulated that paradox back on to the investigator, William C. Smith. Their stories thus offer testimony to a larger historical experience of inequality, to which they responded by rejecting the language of Americanization and defying the effects of assimilation.

One normal-school student wanted to attend college on the continent but learned that "strong racial feelings in the states" would cause her to be "looked upon as a negress." The result? She should have "all privilege barred" from her. She then turned to her experiences in Hawai i, asking, "Why do the haoles come to our islands and create brotherly love and say, 'Let us have peace,' 'Let us have one heart and mind,' [but] deep in their hearts they do not mean what they say." Frustrated with haole who "looked down upon us as browns," she felt that of "all the races" here, Hawaiians seemed "to be given no chances of advancing so that they too may be outstanding in the face of the public." As a result, she advocated replacing white teachers with Native ones or, as she put it, "disposing of some haoles," who held "greater advantages in educational work thereby robbing the others of the same privilege." 101

To many Native students, this "greater advantage" simply meant skin color. One angry normal-school student interrogated a hypothetical white person asking, "Why do the White people have private schools for their children?"

Most likely your answer will be: To protect your child from speaking incorrect English or because the Orientals or other nationalities give

${ }^{101}$ Respondent 197, 10-12. 
the wrong accent to the English words. Is this not drawing a color line? ... The White people have been the very people that have drawn the color line. I have felt this barrier in many circumstances that I have come in contact during my life. ${ }^{102}$

His critique of white people did not end with personal experiences of racial discrimination. His criticism expanded to expose a broader paradox in the DPI mission of promoting "racial harmony":

To create a harmonious atmosphere between the whites and other nationalities is to allow them to mingle with each other. How can they solve the future problems of the world if that color barrier is not done away with? ... They think that God made them to live and eat while the poor colored skin people were made to slave for them. All the different nationalities could work in harmony but the whites could not. Maybe if they would come down from their 'high horses' the world would be working in harmony. ${ }^{103}$

By exposing inconsistencies in the theory and practice of American egalitarianism, Native students refused to accept secondclass treatment. They also resented the importing of American attitudes on racial hierarchy and white privilege that were prevalent on the continent. Upset with the racial double standards and the preferential treatment haole received, one student observed how even ethics and public laws did not apply equally to whites and nonwhites:

If a Haole is able to 'get away' with immorality; immoral dress, immoral speech, immoral thought, immoral conduct, its [ sic] perfectly all right; but just as soon as a Hawaiian ... girl or boy starts the same thing, then the public is down on them; they are criticized and ostracized. This has been proven time and time again from observation.

Not long ago, there was a 'booze raid' in a white family home, but no names were mentioned, the supposition is that if it had been a Hawaiian family or a home of any other race, very likely their names would have been made public. I ask 'Why?' Are the Haoles privileged characters? ${ }^{104}$

Such inconsistencies and double standards extended beyond society and the legal system. Many students observed white privilege in the very institution proselytizing them about the greatness of the American dream: the public school. Hilo High School student John K. Akau felt the DPI was "too political," its leaders "sponsors of race

\footnotetext{
${ }^{102}$ Respondent 195, 8-9.

${ }^{103}$ Respondent 195, 9-10.

${ }^{104}$ Respondent 190, Territorial Normal School, reel 6, 8-9, Life Histories.
} 
prejudice." Even with "all A's," he believed his brown skin made it difficult to "secure a position ... as an instructor." 105 Echoing this sentiment, another Hilo High student queried, "Why should they [the DPI] import the Mainland teachers while we have lots here that may take their place."106

These societal injustices rooted in white American racial attitudes exposed Native students to the adversity their skin color and cultural heritage posed to their lives and future in an Americanized Hawai $i$. While obviously frustrated, Native students refused to allow racism to prevent them from embracing their Indigenous identity, culture, and community. Some were explicit about the ways in which racial discrimination failed to affect their confidence. Defiant and selfassured, one student boldly wrote, "I knew even in grammer [sic] grades that I was different in color from the "haoles' but at no time have I even felt myself or any of my other friends inferior to them." Even when labeled a lazy "kanaka" by various haole, he stood tall, believing that "before God we are all alike and that God does not favor the whites." 107 Others were even more straightforward: "I am 16 years old and I am a part Hawaiian girl. I'm proud of it."108

One of the best and most articulate examples of this Native defiance was Charles W. Kenn, cited at the outset of this article. A graduate of Hawai'i's first public high school, named after President William McKinley, Kenn exemplified the ways in which many Native Hawaiian students resisted assimilation during Hawai'i's territorial years. Like many of his people who attended the territorial public schools, Kenn refused to replace his Native culture, identity, and history with America's. Proud and defiant, Kenn adopted English but rejected Americanization. He thus offered a strong and assertive Native voice at a critical moment in Native Hawaiian history. "I do not want to become a sorry imitation white man," he wrote. "I want to retain some of my own individuality. I want to know something about my own people, and I want to retain that knowledge for posterity. ${ }^{109 "}$

\section{Conclusion}

Walter Johnson, a historian of American slavery, warns against the overuse of "agency" as a theoretical lens when writing the history of

\footnotetext{
${ }^{105}$ Respondent 69, Hilo High School, reel 4, 6, Life Histories.

${ }^{106}$ Respondent 257, Hilo High School, reel 3, 5, Life Histories.

${ }^{107}$ Respondent 60, 9.

${ }^{108}$ Respondent 257, 2.

${ }^{109}$ Kenn, "I Am a Hawaiian," 21.
} 
the less powerful. He argues that agency, as a "master trope," hinders historians from seeing beyond the concept and discovering the myriad ways systems of power both "undermine as well as facilitate" the formations of resistance, solidarity, and community by oppressed groups. ${ }^{110}$

This article takes Johnson's suggestion into consideration. It acknowledges the power of white colonial education and its assimilationist project, but it also recognizes the agency of Native students and their families in retaining their cultural identity and selectively appropriating aspects of American schooling. It concedes that Native students' agency occurred within a context in which these students had few options and made choices under conditions of duress as a colonized people. In this way, it seeks to make sense of Native participation in American education by looking beyond themes of deprivation and victimization to unearth a complicated and dynamic Indigenous response to a settler-colonial society that was actively opposed to Native self-determination. Revisiting this history does not eliminate or reduce the negative impact of Americanization on Native language, culture, and identity, past or present. Instead, it complicates the histories of the territorial period and American education in Hawai'i by revealing the range of Indigenous responses, from active accommodation and disengagement to selective appropriation and overt resistance. This study does not suggest that Native participation in American education was somehow necessary or desirable; rather, it tries to start a new conversation, one that acknowledges the pain of the past while searching for the "cultural forms" that encouraged the "mechanisms" of strength necessary to endure as Native Hawaiians in an Americanized Hawai i ${ }^{111}$

${ }^{110}$ Walter Johnson, “On Agency," Journal of Social History 37, no. 1 (Autumn 2003), 118.

${ }^{111}$ Johnson, “On Agency," 118. 